J-SANAK: Jurnal Kajian Anak

(p-ISSN: 2686-5343 |e-ISSN: 2715-7989)

Vol. (2)(01), (Juli-Desember)(2020), (Halaman)(14-22)

DOI: https://doi.org/10.24127/j-sanak.v2i01.366

\title{
IMPLEMENTASI PERMAINAN SUPER SMART KIDS UNTUK MENINGKATKAN KECERDASAN LOGIKA MATEMATIKA ANAK USIA DINI DI MASA PANDEMI COVID-19
}

\author{
Salpina ${ }^{1}$ \\ Universitas Islam Negeri Sunan Kalijaga \\ salpinasimahate@gmail.com
}

\begin{abstract}
ABSTRAK
Pemerintah telah mengeluarkan kebijakan untuk melakukan pembelajaran dari rumah (learn from home). Hal ini menyebabkan orang tua mendapatkan peran lebih, yakni sebagai guru di rumah. Karena pendidikan harus dilakukan meskipun ditengah wabah Covid-19, begitupun dengan kecerdasan juga tetap harus diberikan stimulus termasuk kecerdasan logika matematika. Dalam upaya memberikan rangsangan pada kecerdasan logika matematika anak, orang tua dapat melakukannya dengan penggunaan permainan, salah satu permainan yang dipercaya dapat mengembangkan kecerdasan logika matematika anak adalah permainan super smart kids. Penelitian ini menggunakan jenis penelitian kualitatif dengan metode deskriptif dengan tehnik pengumpulan data menggunakan wawancara dan observasi. Hasil penelitian menunjukkan bahwa permainan super smart kids dapat diterapkan dirumah, dan anak merasa senang belajar menggunakan permainan ini. Dalam penerapan permainan ini, orang tua harus memperhatikan faktor-faktor yang mempengaruhi permainan super smart kids, agar kecerdasan logika matematika anak dapat terstimulus dengan baik. Selain itu, orang tua juga perlu bekerja sama dengan guru untuk terus berkolaborasi dalam mengoptimalkan kecerdasan anak.
\end{abstract}

Kata Kunci: Permainan Super Smart Kids; Kecerdasan Logika Matematika.

Received 04-11-2020; Received in revised form 16-12-2020; Accepted 16-12-2020.

\begin{abstract}
The government has issued a policy to conduct learning from home (learning from home). This causes parents to get a more role, namely as teachers at home. Because education must be carried out even during the Covid-19 outbreak, as well as intelligence, the stimulus must also be given, including intelligence, mathematical logic. To stimulate children's logical intelligence, parents can use games, one of the games that are not believed to be able to develop children's mathematical intelligence is super smart children's games. This research uses qualitative research with descriptive methods, interviews, and observations. The results showed that super-smart games can be applied at home, and children who enjoy learning to use these games. In the application of this game, parents must pay attention to the factors that influence children's super-intelligent play, so that children's mathematical logic intelligence can be stimulated properly. Besides, parents also need to work together with teachers to continue to collaborate in optimizing children's intelligence.
\end{abstract}

Keywords:Super Smart Kids; Mathematical Logic Intelligence. 


\section{A. PENDAHULUAN}

Tahun 2020 Indonesia dihadapakan dengan tantangan yang sangat berat, kita semua harus dihadapi dengan cobaan virus Corona atau wabah covid-19. Semakin hari jumlah korban yang terjangkit virus ini semakin kian bertambah. Dalam hal ini, pemerintah aknirnya mengambil kebijakan dengan tujuan untuk mengurangi penularan virus corona. Salah satu upaya yang pemerintah berikan adalah adanya himbauan work from home (bekerja dari rumah), pray from home (beribadah dari rumah), dan learn from home (belajar dari rumah) (Dewayani, 2020). Dengan adanya himbauan tersebut, segala aktivitas harus dilakukan dari rumah termasuk kegiatan belajar mengajar. Sekolah-sekolah diliburkan, dan anak-anak harus belajar dari rumah. Sekolah-sekolah diliburkan dan anak-anak belajar dari rumah, hal ini tentu berdampak pada perkembangan anak, salah satunya adalah berdampak pada kecerdasan anak.

Kecerdasan merupakan kemahiran seseorang dalam penyelesaian suatu masalah serta mampu dengan mudah untuk melakukan adaptasi terhadap lingkungan yang baru. Pada hakikatnya, setiap anak telah dianugerahkan kecerdasan masing-masing meskipun pada dasarnya kecerdasan hanya diartikan sebagai sesuatu yang berkaitan dengan akal yakni aspek kognitif yang tertuju pada kecerdasan intellektual. Namun seiring berjalan waktu, definisi kecerdasan mulai diartikan secara luas oleh para ilmuan, seperti yang dikemukakan oleh Howard Gardner bahwa terdapat 9 kecerdasan yang bisa muncul pada diri anak baik salah satu maupun beberapa dan teori ini dikenal dengan teori Multiple Intellegence. Kesembilan kecerdasan itu adalah kecerdasan musical, visual-spasial, verballinguistik, logika matematika, kinestetik, interpersonal, intrapersonal, naturalis, dan eksistensialis.

Salah satu kecerdasan yang patut mendapatkan perhatian adalah kecerdasan logika matematika. Kecerdasan logika matematika berkaitan dengan keahlian dalam pengolahan angka, pengenalan warna serta keterampilan seseorang dalam menggunakan logika dan akal. Seperti yang tertuang dalam PAUD (2014) dijelaskan bahwa anak usia 5-6 tahun sudah mampu untuk berpikir logis. Namun, masalah yang terjadi dilapangan bahwa anak cenderung tidak tertarik untuk belajar matematika. Hal ini disebabkan oleh mindset yang tersimpan dikepala anak bahwa belajar matematika itu sulit karena didalam pelajaran ini anak selalu dihadapkan dengan angka-angka serta rumus. Sesuai dengan data UNESCO dijelaskan bahwa setelah dilakukan pengamatan pada 38 negara, kualitas logis matematika warga Negara Indonesia berada pada peringkat 34. Berdasarkan data diatas, maka dapat disimpulkan bahwa kecerdasan logika matematika sangat rendah serta menjadi materi yang tidak disukai anak.

Akan tetapi, Hamrumi (Hamrumi, 2009) angkat bicara melalui konsep edutainment yang ia kemukakan bahwa pelajaran untuk peserta didik tidak bisa 
diklasifikasikan bahwa pelajaran model ini susah dan itu mudah karena pada dasarnya semua pelajaran itu mudah tergantung bagaimana pembelajaran itu dapat berlangsung sehingga menjadi menyenangkan dan menarik bagi anak. Ia juga menyampaikan suatu pembelajaran tidak akan mancapai tujuan pendidikan jika dijalani dengan proses yang ditakuti anak karena belajar baru akan berhasil jika suasana hati anak senang.

Oleh karena itu, penyajian pembelajaran matematika pada anak usia dini harus disampaikan dengan sebaik mungkin serta menarik, Salah satu cara yang dapat dilakukan agar kecerdasan logika matematika anak dapat berkembang adalah melalui bermain dan permainan, karena hakikatnya karakteristik belajar anak adalah belajar sambil bermain sehingga penggunaan permainan tentu akan memudahkan anak dalam menerima pembelajaran. Sabil (Risaldy, 2015)mengemukakan bahwa bermain adalah prinsip dasar anak usia dini, maka dari itu seorang guru harus memiliki ide-ide untuk mengaitkan segala pembelajaran anak usia dini pada aktivitas bermain maupun melalui alat permainan. Bermain juga memiliki peranan penting bagi tumbuh kembang anak, proses bermain tentu harus didasari pada dorongan sendiri tanpa paksaan, juga bermain mesti menyenangkan serta memberikan pendidikan bagi anak (Ismail, 2006).

Pada hakikatnya, bermain merupakan aktivitas yang anak kerjakan setiap hari, bermain merupakan hidup, dan hidup merupakan permainan. Bagi anak usia dini, tidak ada yang membedakan antara main, kerja dan belajar. Karena anak-anak akan melakukannya dimanapun, kapanpun ada peluang untuk bermain, sehingga cara belajar anak salah satunya adalah melalui bermain (Khadijah, 2012). Melalui bermain aspek-aspek perkembangan anak dapat dikembangkan dengan mudah, serta tidak menutup kemungkinan bahwa bermain juga dapat meningkatkan kecerdasan anak, termasuk kecerdasan logika matematika anak.

Berdasarkan pemaparan diatas, penulis menyimpulkan bahwa kecerdasan logika matematika anak dapat dikembangkan melalui bermain maupun permainan. Pernyataan ini sejalan dengan hasil penelitian Nova Rozi yang menyatakan bahwa kecerdasan logika matematika anak berkembang setelah menggunakan permainan berhitung papan telur (Roza, 2012). Selanjutnya Fadlillah (Fadlilah, 2016) juga melakukan penelitian tentang kecerdasan logika matematika yakni menggunakan permainan Monraket dengan diperoleh hasil rata-rata 3, 94 yang berarti baik. Kemudian Petronella (Suripatty \& Nadiroh Yuliani Nurani, 2020) dalam hasil penelitiannya juga menjelaskan bahwa kecerdasan logika matematika anak meningkat setelah dilakukan pembelajaran melalui permainan Bingo dengan skor $51,93 \%$ pada pra siklus, $63,93 \%$ pada siklus I, dan 74,26\% pada siklus II. Dari hasil siklus tersebut tampak bahwa kecerdasan logika matematika anak terus meningkat pada tiap siklus. 
Sejalan dengan hal diatas, terdapat banyak permainan yang dapat digunakan untuk mengembangkan kecerdasan logika matematika anak seperti permainan balok, permainan congklak, permainan harta karun geometri, bermain puzzle, permainan ular tangga, dan masih banyak lagi. Adapun pada penelitian ini, jenis permainan yang peneliti gunakan adalah permainan super smart kids untuk meningkatkan kecerdasan logika matematika anak. Permainan super smart kids adalah permainan sederhana yang unik dan menarik. Alat dalam permainan ini adalah buku yang dipenuhi dengan soal-soal yang menantang dan membangkitkan rasa ingin tahu anak, serta dilengkapi dengan warna-warna dan bentuk-bentuk yang menarik sehingga membuat anak tidak bosan dan senang melakukan permainan ini.

\section{B. METODOLOGI}

Artikel ini menggunakan jenis penelitian kualitatif dengan metode deskripsi, yakni penelitian yang bersifat alamiah dengan mengambil data-data sesuai keadaan sehingga peneliti menjadi kunci utama pada proses penelitian (Sugiyono, 2015). Penggunaan metode deskripsi dalam artikel ini dikarenakan dalam artikel ini mendiskripsikan penerapan permainan super smart kids. Sampel dalam penelitian adalah beberapa ibu yang memiliki anak usia TK (4-6 tahun) yang berada disekitar tempat tinggal peneliti di Kp. Kenine, KM. 80, Jln. Takengon-Bireuen, Kec. Timang Gajah, Kab. Bener Meriah, Prov. Aceh. Tehnik pengumpulan data dalam artikel ini menggunakan metode wawancara dan observasi. Proses wawancara dan observasi dengan orang tua anak dilakukan melalui penggunaan sosial media berupa whatshap dan zoom. Selain itu, beberapa kali peneliti juga melakukan pertemuan untuk melihat langsung perkembangan kecerdasan logika matematika anak melalui penggunaan permainan super smart kids.

Super smart kids merupakan alat permainan yang membantu mengembangkan kecerdasan logika matematika anak melalui buku dan bantuan petunjuk-petunjuk yang ada dalam buku. Selain dapat mengembangkan kecerdasan logika matematika anak, permainan ini juga dapat digunakan untuk meningkatkan beberapa aspek dari enam aspek perkembangan anak, yaitu aspek bahasa, moral agama, dan seni serta tentu saja aspek kognitif. Permainan super smart kids dilengkapi dengan berbagai permainan yang berbeda-beda pada tiap halaman, serta dilengkapi dengan gambar dan warna yang menarik sehingga anak tidak akan merasa bosan. Pemainan super smart kids dilengkapi dengan sepuluh buku yang terdiri dari tema aqidah Islam, belajar mengaji, asmaul husna, akhlak, mengenal bentuk, membedakan warna, menghitung angka, membaca abjad dan kata, serta bahasa Inggris. Kemudian untuk membantu berlangsungnya permainan ini, juga dilengkapi dengan segi empat lebar yang didalamnya terdiri dari 16 segi empat yang digunakan untuk menjawab tekateki yang diberikan dalam 16 kotak tersebut. 


\section{HASIL DAN PEMBAHASAN}

\section{Implementasi Permainan Super Smart Kids}

Dalam implementasi permainan super smart kids dimasa pandemi, permainan ini sangat cocok dilakukan dengan bantuan bimbingan dari orang tua. Permainan ini dapat dilakukan diwaktu senggang atau diwaktu pagi maupun sore pada saat otak anak fresh dan siap menerima pembelajaran. Sejalan dengan pernyataan Bobi bahwa otak anak akan mudah dalam menerima pembelajaran dan menangkap informasi pada saat otak anak dalam keadaan fresh serta dengan pemberian rangsangan yang menyenangkan (Deporter \& Mike Hernacki, 1999). Dalam permainan Super Smart Kids sama dengan permainan Fun Thinker yakni permainan yang bermaksud untuk mengasah otak dan meningkatkan rasa ingin tahu. Pengaturan dalam permainan ini telah diatur dengan rapi untuk menstimulus kekuatan otak anak dan untuk mengembangkan kekuatan intellektual anak dibagian Start Up. Permainan ini juga menggunakan match frame atau puzzle disertai buku fun Thinker. Desain permainan ini mengarahkan anak untuk dapat mengetahui sendiri seberapa banyak anak tahu atau seberapa banyak anak menjawab benar. Setiap lembar dalam permainan ini dilengkapi dengan gambar-gambar yang berkarakter serta anak akan dihadapkan dengan berbagai tantangan sehingga akan mengasah otak anak, kreativitas serta logika berpikirnya.

Pemainan super smart kids ini memiliki sepuluh buku yang terdiri dari tema aqidah Islam, belajar mengaji, asmaul husna, akhlak, mengenal bentuk, membedakan warna, menghitung angka, membaca abjad dan kata, serta bahasa Inggris. Pada penelitian ini peneliti hanya menggunakan permainan super smart kids pada bagian menghitung angka. Adapun tahapan permainan ini adalah anakanak diarahkan untuk menyusun kotak-kotak angka 1-16, untuk pelaksanaannya anak harus membaca petunjuk/instruksi yang ada sibelah kiri atas buku, misalnya menyesuaikan warna, menyesuaikan urutan angka, mencocokkan kata dengan angka serta gambar, dan sebagainya, kemudian anak-anak menjawab tantangan berdasarkan instruksi dan menyusun angka bentuk kotak 1-16 sesuai dengan jawaban yang benar diisi disebelah kanan, untuk mengetahui jawaban anak benar atau tidak bingkai kotak-kotak ditutup terlebih dahulu dan dibalik. Jika bingkai kotak-kotak telah berbentuk sesuai gambar yang ada diatas kanan buku maka berarti jawaban anak benar. 
Gambar 1. Gambar Anak Memainkan Permainan Super Smart Kids

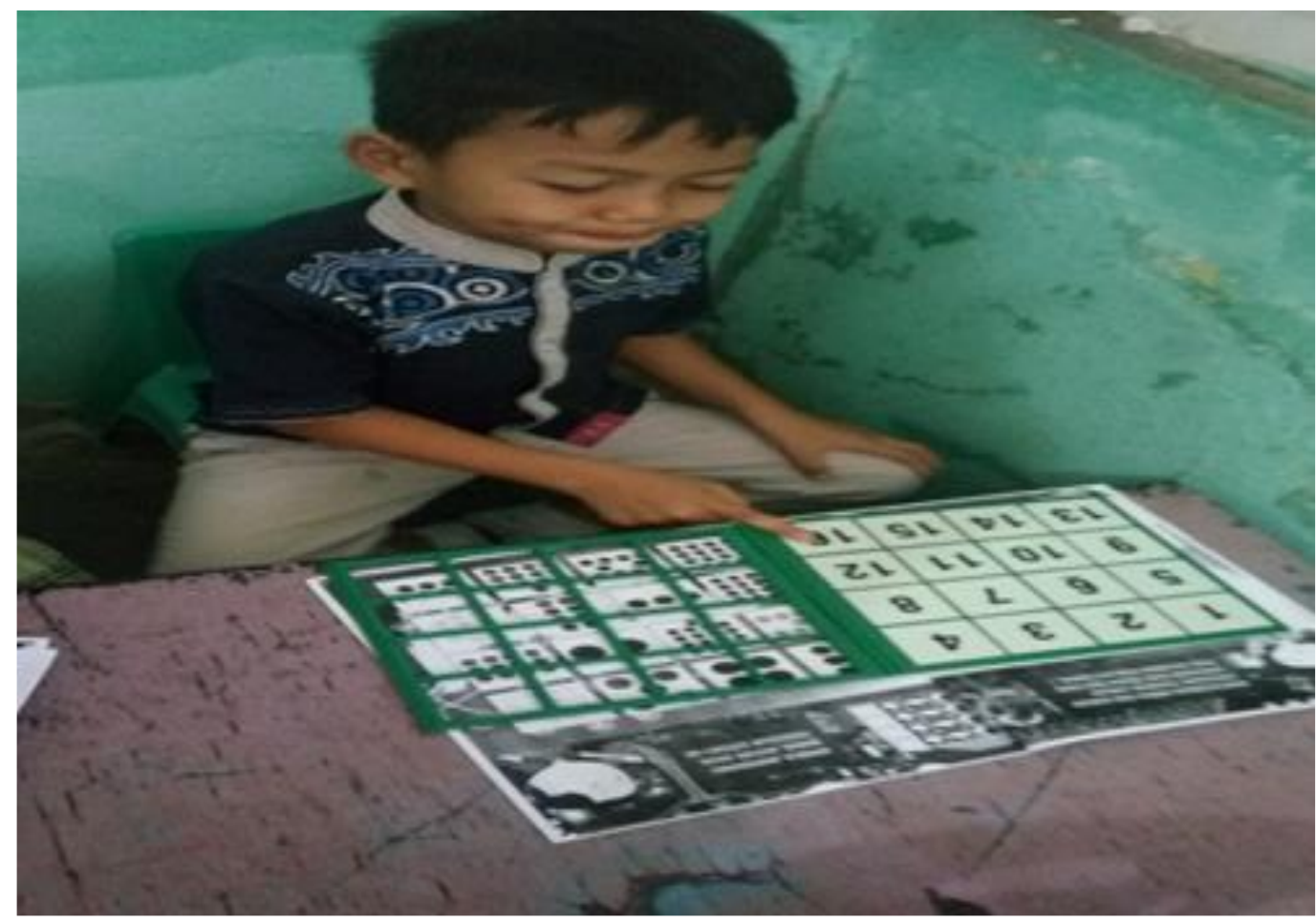

Manfaat dari penerapan permainan super smart kids ini adalah membantu anak dalam membangun koordinasi dengan konsentrasi untuk menyelesaikan masalah untuk meningkatkan skill bidang matematika, kemampuan berpikir dengan mudah dan menyenangkan. Belajar melalui kombinasi angka dan gambar untuk meningkatkan kecepatan berpikir anak. Selain itu, permainan ini dapat melatih keseimbangan otak kanan dan kiri anak. Jika dalam belajar anak telah menemukan cara yang tepat dan mudah, maka perasaan cepat bosan dan lelah akan terlupakan oleh anak, dan berubah menjadi semangat untuk terus berulang kembali memainkan permainannya sampai anak mampu bermain sendiri. Target dari permainan ini adalah anak mampu menjawab pertanyaan dengan tepat dan cepat, kemudian anak dapat bermain dengan hati senang. Sehingga rangsangan otak anak dapat bekerja secara sistematis pada masa perkembangan dan pertumbuhannya (Kamil Pustaka Team, 2016).

Dari uraian tentang implementasi permainan super smart kids diatas, dapat disimpulkan bahwa permainan ini dapat meningkatkan kecrdasan logika matematika anak. Kecerdasan logika matematika bukan hanya berkaitan dengan angka-angka, namun juga kemampuan anak untuk berpikir logis, dapat menalar dengan kritis, mudah memecahkan teka teki, dan banyak lagi. Tentu saja dalam permainan ini dapat mengasah semua kemampuan-kemampuan yang berkaitan dengan kecerdasan logika matematika. Pemecahan teka-teki terdapat saat anak hendak menyelesaikan permainan dengan menjawab teka-teki yang ada dalam 
J-SANAK: Jurnal Kajian Anak

(p-ISSN: 2686-5343 le-ISSN: 2715-7989)

Vol. (2)(01), (Juli-Desember)(2020), (Halaman)(14-22)

DOI: https://doi.org/10.24127/j-sanak.v2i01.366

pertanyaan, kegiatan menalar anak lakukan saat harus memberikan jawaban dalam kotak dan tentu saja dalam permainan ini dilengkapi dengan angka-angka sehingga dapat mengasah kecerdasan logika matematika anak.

\section{Faktor yang Mempengaruhi Permainan Super Smart Kids}

Setiap permainan maupun kegiatan suatu program tentu memiliki faktor-faktor yang mempengaruhi keberlangsungan permainan atau program tersebut. Begitu juga dengan permainan super smart kids ini terdapat beberapa faktor-faktor yang mempengaruhinya, diantaranya:

1. Peran Orang Tua

Orang tua memiliki peranan penting untuk terus mendukung dan menstimulasi perkembangan anak termasuk kecerdasan logika matematika anak. Peran orang tua dimasa pandemi bertambah sebagai yakni menjadi guru bagi anak-anaknya. Orang tua perlu meluangkan waktu untuk mendidik anak, serta memprioritaskan anak dari pada kesibukannya. Jika orang tua bersemangat memberikan rangsangan pendidikan pada anak, maka anak juga akan memiliki semangat yang tinggi dalam menerima pembelajaran, serta menimbulkan rasa senang pada diri anak. Begitupun dalam permainan super smart kids, permainan ini membutuhkan peran aktif dari orang tua agar anak-anak dapat dengan mudah mendapatkan jawabannya serta menyusun kepingan kembali. Orang tua perlu untuk memberikan semangat agar anak tetap bersemangat dan tidak mudah bosan.

2. Kemauan Anak

Setiap permainan yang dimainkan oleh anak tentu harus berdasarkan kemauan anak itu sendiri, tidak dengan paksaan orang sekitar. Oleh karena itu kembali pada peran orang tua untuk meningkatkan antusias anak melalui caracara yang menyenangkan. Pembelajaran menjadi menyenangkan jika disampaikan oleh orang yang menyenangkan. Sebaliknya pembelajaran yang mudah sekalipun akan terasa membosankan jika disampaikan guru/orang tua yang tidak menyenagkan.maka orang tua perlu mempelajari cara-cara menenangkan untuk meningkatkan kemauan anak untuk belajar (Mulyati, 2019).

3. Lingkungan yang Baik

Lingkungan yang baik untuk menstimulus perkembangan anak adalah lingkungan yang selalu memberikan dukungan terhadap anak, tidak memberikan ejekan-ejekan berupa pelabelan pada anak yang dapat membuat anak down dan tidak percaya diri. Lingkungan terbagi menjadi tiga yakni lingkungan sekolah, lingkungan masyarakat, dan lingkungan keluarga (Musfiqon, 2012). Lingkungan keluarga/rumah biasanya mencakup peran nenek, kakek, ayah, ibu, kakak dan adik. Dalam memainkan permainan super smart kids anak-anak perlu diberikan 
J-SANAK: Jurnal Kajian Anak

(p-ISSN: 2686-5343 |e-ISSN: 2715-7989)

Vol. (2)(01), (Juli-Desember)(2020), (Halaman)(14-22)

DOI: https://doi.org/10.24127/j-sanak.v2i01.366

dukungan dari keluarga agar anak tetap semangat melakukan permainannya. Sama halnya dalam mengembangkan kecerdasan logika matematika anak, lingkungan yang baik tentu dapat memudahkan proses pengasahan kecerdasannya.

4. Fasilitas

Fasilitas adalah hal utama yang dapat menunjang keberhasilan proses pendidikan, termasuk dalam mengembangkan kecerdasan logika matematika anak. Fasilitas yang diberikan dapat berupa alat permainan edukatif yang dapat menstimulus kecerdasan logika matematika anak. Selain itu, dengan memberikan fasilitas berupa alat permainan anak-anak akan lenih antusias dalam menerima rangsangan pembelajaran. Dengan menggunakan alat permainan super smart kids orang tua dapat mengembangkan kecerdasan logika matematika anak dengan lebih mudah.

\section{KESIMPULAN}

Pemainan super smart kids merupakan permainan yang dipercaya dapat meningkatkan kecerdasan logika matematika anak. dalam penerapannya, guru dan orang tua dapat bekerja sama dalam memberikan rangsangan pada anak dimasa pandemi sepertin sekarang ini. Meskipun anak-anak tidak diizinkan untuk sekolah karena masih diliburkan, pendidikan tetap harus diberikan dan tidak boleh terhenti, ini berarti orang tua memiliki peranan penting dalam mengoptimalkan pertumbuhan dan perkembangan anak, termasuk kecerdasan logika matematika anak. Penggunaan permainan super smart kids bermanfaat untuk melatih keseimbangan otak kanan dan kiri anak, kemampuan berpikir dengan mudah dan menyenangkan serta belajar melalui kombinasi angka dan gambar untuk meningkatkan kecepatan berpikir anak. berdasarkan hal ini, permainan super smart kids sangat cocok untuk diterapkan pada anak usia dini untuk melatih kecerdasan logika matematika anak.

\section{E. DAFTAR PUSTAKA}

Deporter, B., \& Mike Hernacki. (1999). Quantum Lerning. Kaifa.

Dewayani, T. (2020). Bekerja Dari Rumah (Work From Home) Dari Sudut Pandang Unit Kepatuhan. <https://Www.Djkn.Kemenkeu.Go.Id/Artikel/Baca/13014/Bekerja-Dari

Rumah-Bekerja-Dari-Rumah-Sudut-Pandang-Unit-KepatuhanInternal.Html>.

Fadlilah. (2016). Pengembangan Permainan Monraked Sebagai Media Untuk Menstimulasi Kecerdasan Logika Matematika Anak Usia Dini. CARE (Children ADvisory Research And Education), 4(1).

Hamrumi. (2009). Edutainment Dalam Pendidikan Islam dan Teori-Teori Pembelajaran Quantum. Universitas Islam Negeri Sunan Klijaga.

Ismail, A. (2006). Education Games. Pilar Media. 
J-SANAK: Jurnal Kajian Anak

(p-ISSN: 2686-5343 |e-ISSN: 2715-7989)

Vol. (2)(01), (Juli-Desember)(2020), (Halaman)(14-22)

DOI: https://doi.org/10.24127/j-sanak.v2i01.366

Kamil Pustaka Team. (2016). Super Smart Kids, Anakku Cerdas dan Kreatif (Menghitung Angka). Kamil Pustaka.

Khadijah. (2012). Konsep Dasar Pendidikan Pra Sekolah. Cita Pustaka Media Perintis.

Mulyati, M. (2019). Menciptakan Pembelajaran Menyenangkan Dalam Menumbuhkan Peminatan Anak Usia Dini Terhadap Pelajaran. Alim Jurnal of Islamic Education, 1(2), 277-294.

Musfiqon. (2012). Pengembangan Media dan Sumber Pembelajaran. PT. Prestasi Pustakaraya.

Risaldy, S. (2015). Bermain, Bercerita dan Bernyanyi Bagi Anak Usia Dini. Luxima Metro Media.

Roza, N. (2012). Peningkatan Kecerdasan Logika Matematika Anak Melalui Permainan Berhitung. Ilmih Pesona PAUD, 04(1), 1-10.

Sugiyono. (2015). Cara Mudah Menyusun Skripsi, Tesis, dan Disertasi (Bandung). Alfabeta.

Suripatty, P., \& Nadiroh Yuliani Nurani. (2020). Peningkatan Kecerdasan Logika Matematika Melalui Permainan Bingo. Obsesi, 4(1), 100-109. 